\title{
Environment and chronic kidney disease in farmers
}

\author{
Kei Nagai ${ }^{1,2^{*}}$
}

\begin{abstract}
The prevalence of chronic kidney disease (CKD) has been on the rise worldwide. Epidemiological studies performed primarily in Central America and South Asia have reported high prevalence of CKD among young and middle-aged men working in agricultural communities. The clinical features do not appear linked to any classical CKD risk factors, such as hypertension, diabetes, or chronic nephritis. The disease develops and progresses as interstitial nephritis, without showing noticeable symptoms or high levels of proteinuria. Pathologically, the disease essentially represents chronic interstitial nephritis and is termed chronic interstitial nephritis in agricultural communities (CINAC). The potential causes of CINAC include: (1) heat stress-related factors associated with increased ambient temperatures resulting from global warming; and (2) factors connected with exposure to agrochemicals and/or pesticides. Global warming and environmental pollution will undoubtedly pose a significant health risk to farmers, and heat stress during farm work could easily result in the development and progression of CKD. Japanese agricultural regions evidently will not be spared from global environmental changes. For future epidemiological studies, researchers should establish a more comprehensive analytical method that can incorporate additional risk-factor variables, such as occupational history (including agricultural work) and ambient temperature.
\end{abstract}

Keywords: Chronic kidney disease, Dehydration, Heat stress, Farmers

\section{Introduction}

Chronic kidney disease (CKD) is primarily caused by chronic glomerulonephritis, diabetes, or hypertension. In 2017, the global prevalence of CKD was 9.1\% [1]. Patients with advanced CKD require renal replacement therapy, significantly impacting their healthcare costs and quality of life. In the past, causes of CKD were often specific renal disorders such as chronic glomerulonephritis and polycystic kidney disease. However, in recent years, an increasing number of patients have initiated maintenance dialysis due to non-specific renal disorders (e.g., diabetic nephropathy and hypertensive nephropathy) associated with aging or lifestyle-related diseases [2]. Moreover, etiologies of CKD cannot even be clarified in a certain

*Correspondence: knagai@md.tsukuba.ac.jp

${ }^{1}$ Department of Nephrology, Hitachi General Hospital, 2-1-1 Jonan-cho, Hitachi, Ibaraki 317-0077, Japan

Full list of author information is available at the end of the article number of Japanese patients undergoing chronic dialysis [2].

Recently, environmental and occupational risk factors have drawn global attention as potential causes of CKD, promoting epidemiological studies, pathophysiological assessments, and experimental pathological verification of these risk factors. The results have revealed the prevalence of CKD not only in high-income nations, but also in low- and middle-income countries and regions. In these developing countries and regions, certain individuals without commonly known CKD risk factors (i.e., aging, hypertension, and diabetes) present with kidney injury and progress to end-stage renal failure that requires renal replacement therapy [3].

In this review article, we provide an overview of CKD and its risk factors identified from different agricultural communities around the world. I then describe the original author(s) and the source, provide a link to the Creative Commons licence, and indicate if changes were made. The images or other third party material in this article are included in the article's Creative Commons licence, unless indicated otherwise in a credit line to the material. If material is not included in the article's Creative Commons licence and your intended use is not permitted by statutory regulation or exceeds the permitted use, you will need to obtain permission directly from the copyright holder. To view a copy of this licence, visit http://creativecommons.org/licenses/by/4.0/. The Creative Commons Public Domain Dedication waiver (http://creativecommons.org/publicdomain/zero/1.0/) applies to the data made available in this article, unless otherwise stated in a credit line to the data. 
current knowledge about the possible mechanisms of kidney injury in farmers.

\section{Epidemiological evidence for hot spots of chronic kidney disease in the agricultural community}

Descriptive research into CKD occurring frequently in agricultural workers was initiated in 2002 in Central America [4]. In El Salvador, CKD and end-stage renal failure had been frequently observed among young workers in sugarcane fields since the 1990s, and the number of patients with these kidney diseases had been showing an increasing tendency. These patients did not exhibit any classical risk factors of CKD, such as hypertension, diabetes, or glomerular diseases. A similar phenomenon was also observed in different regions of Central America, including Costa Rica [5] and Nicaragua [6]. These kidney diseases are thus now collectively referred to as Mesoamerican nephropathy $(\mathrm{MeN})$, based on the geographical features of their origins [7]. $\mathrm{MeN}$ is also called chronic interstitial nephritis in agricultural communities (CINAC). This is because the disease rarely shows the characteristics of glomerular injury (such as proteinuria), and is defined by its clinical features (primarily renal tubular injury) and pathological hallmarks (chronic interstitial nephritis) [8]. Sugarcane field workers tend to experience repeated episodes of acute kidney injury (AKI) that is caused, for example, by dehydration during work hours [9]. This leads to gradual decreases in renal function over the course of a harvest season, ultimately progressing to CKD. The prevalence of CKD is thus high among sugarcane farmers. In addition to sugarcane work, other types of physical labor (such as cotton farming, corn growing, and construction work) can also cause CINAC $[6,10]$. A common feature associated with these occupations is long, physically intensive labor performed by young men in low-altitude farmland [11]. This suggests that the clinical conditions of CINAC patients are caused by a common mechanism involving heat-induced recurrent AKI.

Similar to MeN, CKD not attributable to any classical risk factors has frequently been identified in Sri Lanka since the 1990s [12]. Patients with this kidney disease are predominantly male and between 40 and 50 years old. Cases are initially asymptomatic and the kidney injury progresses with no increase in urinary protein levels. Pathologically, this disease is a chronic interstitial nephritis and its pathophysiology is similar to that of $\mathrm{MeN}[13,14]$. One difference between $\mathrm{MeN}$ and Sri Lankan nephropathy is the working environments, with patients in Central America generally working in sugarcane, cotton, and corn fields, and those in Sri Lanka mainly growing rice in paddy fields [15]. Agricultural workers in Central America and Sri Lanka are thus likely exposed to slightly different types and quantities of water pollutants (i.e., chemical agents and heavy metals) [15].

Hotspots of "CKD with no associated classical risk factors" have been reported in other regions of the world. Kidney diseases in these hotspots as well as $\mathrm{MeN}$ and Sri Lankan nephropathy are collectively termed CKD of unknown etiology (CKDu) [3]. In Central India, $\mathrm{CKDu}$ is also called "Uddanam nephropathy", named after a typical village in the state of Andhra Pradesh. In the 1990s, chronic interstitial nephritis found in this Indian region was reported to account for a significant proportion of the clinical features of 2,028 patients with renal failure [16]. Following this first report, a systematic epidemiological study was performed [17]. Hotspots of CKDu have also been identified in Mexico [18], Egypt [19] and others shown in Table 1.

We acknowledge that CINAC exists as a clinical condition. However, a few words of caution are required when discussing its prevalence. Chronic renal dysfunction inevitably occurs with aging and thus can be regarded as one of the natural changes in physiological function $[20,21]$. This is similar to the fact that arteriosclerosis is accompanied by high blood pressure. Accordingly, as the proportion of hypertensive patients increases in the elderly, the prevalence of CKD rises with age. As for the CKD studies reported from various parts of the world, an important point to note is that sample cohort sizes are usually small. Moreover, certain publications do not show the age-stratified or age-adjusted prevalence of CKD (Table 1). CKD is diagnosed based on the positive results of kidney injury and urinary protein tests, each of which is performed twice with $\mathrm{a} \geq 3$-month interval. However, the majority of epidemiological studies of CKDu have lacked proof of chronicity, failing to strictly differentiate between CKD and AKI [22]. Furthermore, although the diagnosis of CKD in younger patients is commonly established based on a positive proteinuria alone [23], urinalysis results have often not been included in cohort data [24]. The diagnosis of CKD can also be made based on serum creatinine levels. Creatinine is an endogenous metabolic product, and its serum levels are dependent on muscle mass. Consequently, if agricultural workers who participate in clinical studies are physically active and have a high muscle mass, researchers may overestimate the prevalence of CKD.

CKD studies reported from many different locations have shown these kinds of weaknesses in providing scientifically accurate data on prevalence, but have generally shown an increased proportion of CKD patients among young and middle-aged men in agricultural community [24]. 
Table 1 Original evidence of kidney disease in agricultural communities

\begin{tabular}{|c|c|c|c|}
\hline $\begin{array}{l}\text { Nation } \\
\text { Region }\end{array}$ & Study design, participants, age & Main findings & References \\
\hline $\begin{array}{l}\text { El Salvador } \\
\text { Bajo Lempa }\end{array}$ & $\begin{array}{l}775 \text { individuals: } 88.3 \% \text { of total resident population in } \\
\text { the region } \\
\text { Mean age: } 39 \text { years }\end{array}$ & $\begin{array}{l}\text { Prevalence of CKD was } 17.9 \% \text { (men, } 25.7 \% \text {; women, } \\
11.8 \% \text { ), higher than that reported internationally }\end{array}$ & [34] \\
\hline $\begin{array}{l}\text { El Salvador } \\
\text { Five communities }\end{array}$ & $\begin{array}{l}1184 \text { general population without previous kidney } \\
\text { problems } \\
37 \pm 11 \text { years }\end{array}$ & $\begin{array}{l}\text { Among men in coastal communities, } 18 \% \text { had } \\
\text { eGFR }<60 \mathrm{~mL} / \mathrm{min} / 1.73 \mathrm{~m}^{2} \text { compared with } 4 \% \\
\text { and } 1 \% \text { in communities } 500 \mathrm{~m} \text { above sea level. For } \\
\text { agricultural workers, prevalence of reduced eGFR was } \\
\text { highest for coastal sugarcane workers }\end{array}$ & [10] \\
\hline $\begin{array}{l}\text { Nicaragua } \\
\text { Chinandega and León }\end{array}$ & $\begin{array}{l}194 \text { male workers } \\
17-39 \text { years }\end{array}$ & $\begin{array}{l}\text { Reduced eGFR occurred in } 16 \%, 9 \% \text { and } 2 \% \text { of sugar- } \\
\text { cane cutters, construct workers and small-scale farm- } \\
\text { ers, respectively. Mean age did not differ significantly } \\
\text { between occupations }\end{array}$ & [35] \\
\hline $\begin{array}{l}\text { Nicaragua } \\
\text { León }\end{array}$ & $\begin{array}{l}2275 \text { general population-based cohort } \\
\text { Age 18-70 years }\end{array}$ & $\begin{array}{l}\text { CKD prevalence was } 9.1 \% \text { overall; } 13.8 \% \text { for men and } \\
5.8 \% \text { for women. Low education level and more years } \\
\text { of agricultural work were significantly associated with } \\
\text { CKD }\end{array}$ & [24] \\
\hline $\begin{array}{l}\text { Sri Lanka } \\
\text { Three rural areas (North } \\
\text { Central, Central, South- } \\
\text { ern) }\end{array}$ & $\begin{array}{l}6153 \text { people from random cluster sampling method, } \\
\text { age } 20-96 \text { years }\end{array}$ & $\begin{array}{l}\text { Proteinuric CKD of uncertain etiology was prevalent } \\
\text { in the North Central area. Age, sex, occupation as a } \\
\text { farmer, and exposure to agrochemicals were potential } \\
\text { risk factors for CKD }\end{array}$ & [36] \\
\hline $\begin{array}{l}\text { India } \\
\text { Andhra Pradesh }\end{array}$ & $\begin{array}{l}1184 \text { adults through random sampling } \\
45 \pm 14 \text { years }\end{array}$ & $\begin{array}{l}\text { Prevalence of CKD } 32.2 \% \text {. Farmers ( } 44.2 \% \text { of subjects) } \\
\text { showed a } 20 \% \text { greater prevalence of CKD compared } \\
\text { to non-farmers in the fully adjusted model }\end{array}$ & {$[17]$} \\
\hline $\begin{array}{l}\text { Egypt } \\
\text { Upper Egypt } \\
\text { El-Minia }\end{array}$ & $\begin{array}{l}800 \text { patients on renal replacement therapy } \\
\text { Mean age, } 46 \text { years }\end{array}$ & $\begin{array}{l}\text { Main occupation was farming. Unknown etiology, at } \\
27 \% \text {, was a leading cause of end-stage kidney disease }\end{array}$ & [19] \\
\hline $\begin{array}{l}\text { Indonesia } \\
\text { West Java }\end{array}$ & $\begin{array}{l}354 \text { healthy young Javanese rice farmers } \\
\geq 50 \text { years, } n=197 \\
<50 \text { years, } n=157\end{array}$ & $\begin{array}{l}\text { Overall prevalences were } 24.9 \% \text { for CKD and } 18.6 \% \\
\text { for CKDu. Odds ratio for high altitude was } 2.0(95 \% \mathrm{Cl} \text {, } \\
1.2-3.5) \text { and longer use of insecticide and its fre- } \\
\text { quency also seemed to represent risks }\end{array}$ & {$[37]$} \\
\hline $\begin{array}{l}\text { Mexico } \\
\text { Tierra Blanca }\end{array}$ & $\begin{array}{l}579 \text { healthy people with any occupations } \\
42 \text { years (IQR, 31-50 years) }\end{array}$ & $\begin{array}{l}\text { Age- and sex-adjusted prevalence of low eGFR was } \\
3.5 \% \text { in the total cohort. Agriculture was the occupa- } \\
\text { tion with the highest adjusted prevalence of low } \\
\text { eGFR ( } 8.8 \%) \text {, associated with a > fivefold risk of low } \\
\text { eGFR }\end{array}$ & [18] \\
\hline
\end{tabular}

CKD, chronic kidney disease; eGFR, estimated glomerular filtration ratio; CKDu, CKD of unknown etiology; IQR, interquartile range

\section{Putative etiology of occupational kidney injury related to agriculture}

CINAC is defined based on the following patient characteristics [13]: (a) living or working in agricultural communities; (b) a lack of typical risk factors for CKD (including diabetes and hypertension); and (c) low levels of proteinuria. Similar to the clinical features of chronic interstitial nephritis, the kidneys in CINAC patients are small and display a thin cortex with increased echogenicity [13]. Risk factors for CKD identified to date that appear related to agricultural work include: elevated water intake, as a proxy for excessive work hours and/or heat stress [11]; high ambient temperature [25]; heavy metals in soil [3]; agrochemicals (fertilizers and pesticides) [26]; and low-quality drinking water [27] (Fig. 1). CKD is considered to progress at a different pace depending on the degree of exposure to these risk factors [13]. Perspiration from heat stress could conceivably lead to the excessive loss of body fluids (i.e., electrolyte-containing water), resulting in kidney injury. Dehydration can also potentially cause a variety of clinical conditions, including hyperuricemia and rhabdomyolysis. CINAC thus likely arises through combinations of these different pathological processes [28]. However, assuming that kidney injury is caused solely by events triggered by global warming would be unrealistic. In fact, one of the current hypotheses concerning the pathogenesis of CINAC proposes that MeN is associated with high temperatures, while agricultural chemicals are the primary cause of CKDu in South Asia. Some researchers have therefore suggested that $\mathrm{CKDu}$ should be called "agrochemical nephropathy", rather than "global-warming nephropathy" [29-31].

Currently, no direct evidence suggests that the development of CKD in agricultural workers is associated 


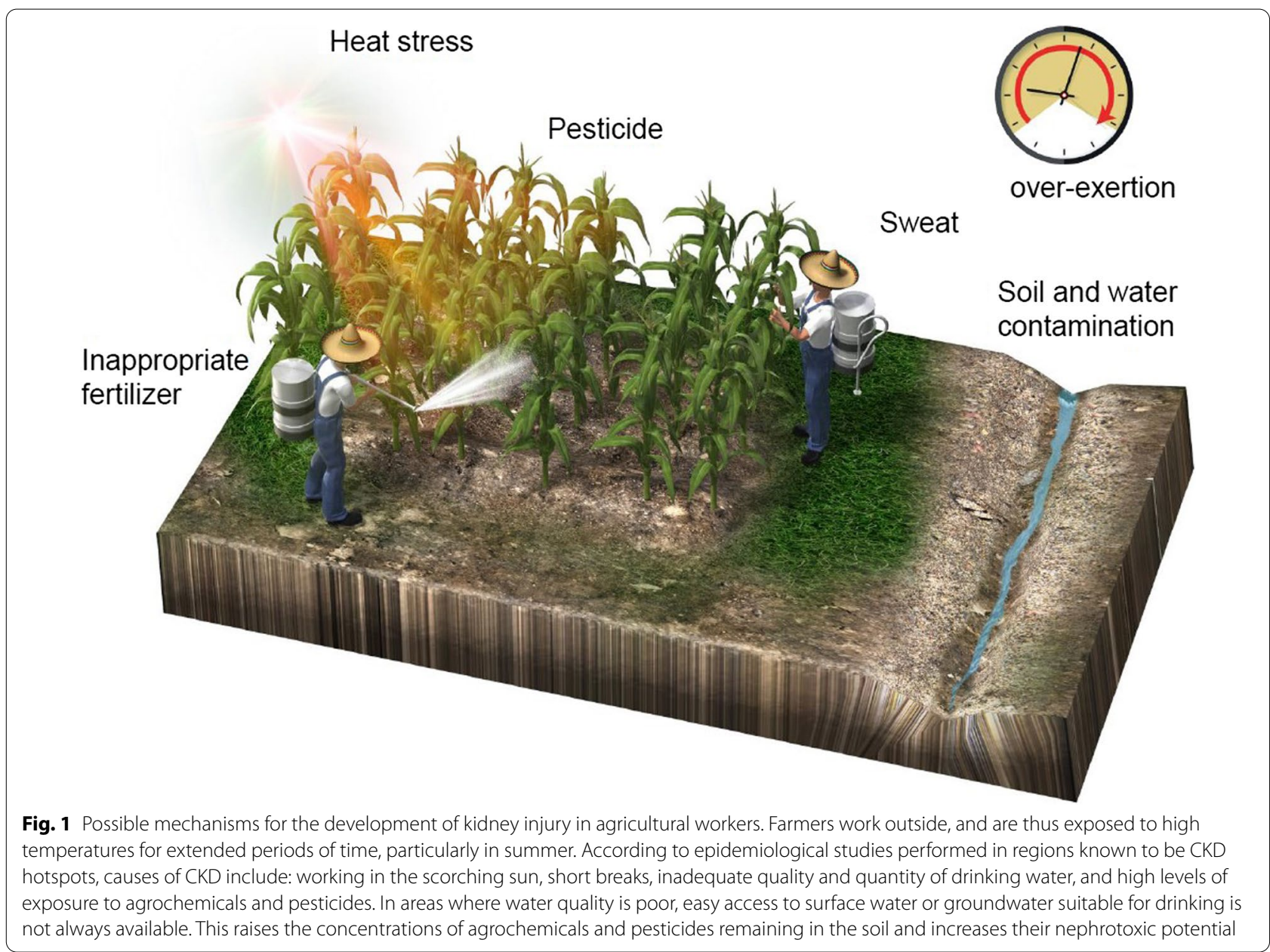

with exposure to agrochemicals, pesticides, or mixtures of both. However, pathological studies have clearly indicated that kidney injury can be caused by agrochemicals and pesticides contaminated with heavy metals or organic solvents [30]. Moreover, a recent collaborative research demonstrated 34 renal biopsies from Sri Lanka, El Salvador, India and France of patient with CINAC [8]. In addition to usual histopathology of chronic interstitial nephritis, the authors identified a unique constellation of proximal tubular cell including large dysmorphic lysosomes with a light-medium electron-dense matrix in CINAC mainly due to nephrotoxic chemicals. As this feature was also observed in renal histology of calcinurin inhibitor treated transplant patients, they suggested CINAC patients underwent a tubulotoxic mechanism similar to calcineurin inhibitor nephropathy [8]. As climate change persists, water resources (such as rivers and wells) are depleting, and this could lead to higher concentrations of agrochemicals in drinking water [32]. As a result, although the use of potentially harmful agrochemicals and pesticides has recently decreased, agricultural workers and residents in agricultural communities can still be exposed to high levels of chemical compounds that could cause CKDu [33]. Eliminating the risk of CKD thus remains a challenging task.

\section{Need for investigating chronic kidney disease in the agricultural community}

From the perspective of industrial health care, scientifically proving that certain occupations are linked to increased risks of specific types of chronic disease is important. For example, heat stress-induced renal dysfunction caused by sugarcane field labor correlates with reductions in crop yields and worker productivity [25]. The results of such analyses could be useful as a basis for the development of, for example, safety measures aimed at protecting workers from solar irradiation. Such data should also prove instrumental for managing work hours suitable for productive business operations. Regarding our society, no direct evidence has been published in Japan regarding changes in the prevalence of CKD, 
when this disease is considered a health problem associated with temperature increases. However, Japanese agricultural regions evidently will not be spared from global environmental changes. In this context, medical history and the results of health checkup (collectively called medical information) are insufficient for determining the etiology of CKD in previously conducted investigations. For future epidemiological studies in Japan, researchers should establish a more comprehensive analytical method that can incorporate additional risk-factor variables, such as occupational history (including agricultural work), ambient temperature and history of exposures to environmental pollutants.

\section{Conclusion}

Based on the clinical features and pathological characteristics identified in agricultural workers from CKD hotspots outside Japan, CINAC clearly represents a genuine public health issue. However, no conclusion has yet been reached regarding whether the prevalence of overall CKD is indeed higher among agricultural communities. This is partly because the epidemiological methodologies used for validating this correlation have sometimes been inadequate. The causes of CINAC include heat stressand agrochemical-induced kidney injuries, suggesting that complex mechanisms underlie this pathogenesis. Furthermore, the main causes of CINAC appear to vary between different hotspots. In Japan, only a limited number of studies have thus far analyzed the prevalence of CKD in agricultural workers. However, Japanese agricultural regions evidently will not be spared from global warming in the future. It is desirable to practice epidemiological investigation focusing on the environment and occupation.

\section{Abbreviations}

CKD: Chronic kidney disease; CINAC: Chronic interstitial nephritis in agricultural communities; MeN: Mesoamerican nephropathy; AKI: Acute kidney injury; CKDu: CKD of unknown etiology.

\section{Acknowledgements}

None.

\section{Authors' contributions}

KN wrote the manuscript. The author approved the final manuscript.

\section{Funding}

This article was supported, in part, by JSPS Grant No. 18KK0431 and by the Japanese Association of Dialysis Physicians Grant No. 2019-1.

\section{Availability of data and materials}

Not applicable.

\section{Declarations}

Ethics approval and consent to participate Not applicable.

\section{Consent for publication}

The author confirms for publication.

\section{Competing interests}

The author declares that the review work was conducted in the absence of any commercial or financial relationships that could be construed as a potential conflict of interest.

\section{Author details}

'Department of Nephrology, Hitachi General Hospital, 2-1-1 Jonan-cho, Hitachi, Ibaraki 317-0077, Japan. ${ }^{2}$ University of Tsukuba Hospital Hitachi Social Cooperation Education Research Center, 1-1-1 Tennodai, Tsukuba, Ibaraki 305-8575, Japan.

Received: 28 August 2021 Accepted: 3 October 2021

Published online: 13 October 2021

\section{References}

1. Collaboration GBDCKD. Global, regional, and national burden of chronic kidney disease, 1990-2017: a systematic analysis for the Global Burden of Disease Study 2017. Lancet. 2020;395(10225):709-33.

2. Nakai $\mathrm{S}$, Iseki $\mathrm{K}$, Itami $\mathrm{N}$, et al. Overview of regular dialysis treatment in Japan (as of 31 December 2009). Ther Apher Dial. 2012;16(1):11-53.

3. Lunyera J, Mohottige D, Von Isenburg M, et al. CKD of uncertain etiology: a systematic review. Clin J Am Soc Nephrol. 2016;11(3):379-85.

4. Trabanino RG, Aguilar R, Silva CR, et al. End-stage renal disease among patients in a referral hospital in El Salvador. Rev Panam Salud Publica. 2002;12(3):202-6 (in Spanish).

5. Wesseling C, van Wendel de Joode B, Crowe J, et al. Mesoamerican nephropathy: geographical distribution and time trends of chronic kidney disease mortality between 1970 and 2012 in Costa Rica. Occup Environ Med. 2015;72(10):714-21.

6. Torres C, Aragon A, Gonzalez M, et al. Decreased kidney function of unknown cause in Nicaragua: a community-based survey. Am J Kidney Dis. 2010;55(3):485-96.

7. Correa-Rotter R, Wesseling C, Johnson RJ. CKD of unknown origin in Central America: the case for a Mesoamerican nephropathy. Am J Kidney Dis. 2014;63(3):506-20.

8. Vervaet BA, Nast CC, Jayasumana C, et al. Chronic interstitial nephritis in agricultural communities is a toxin-induced proximal tubular nephropathy. Kidney Int. 2020;97(2):350-69.

9. Wesseling C, Aragon A, Gonzalez M, et al. Kidney function in sugarcane cutters in Nicaragua - a longitudinal study of workers at risk of Mesoamerican nephropathy. Environ Res. 2016;147:125-32.

10. Peraza S, Wesseling C, Aragon A, et al. Decreased kidney function among agricultural workers in El Salvador. Am J Kidney Dis. 2012;59(4):531-40.

11. Gonzalez-Quiroz M, Pearce N, Caplin B, et al. What do epidemiological studies tell us about chronic kidney disease of undetermined cause in Meso-America? A systematic review and meta-analysis. Clin Kidney J. 2018;11(4):496-506.

12. Wanigasuriya KP, Peiris-John RJ, Wickremasinghe R, et al. Chronic renal failure in North Central Province of Sri Lanka: an environmentally induced disease. Trans R Soc Trop Med Hyg. 2007;101(10):1013-7.

13. Jayasumana $C$, Orantes $C$, Herrera R, et al. Chronic interstitial nephritis in agricultural communities: a worldwide epidemic with social, occupational and environmental determinants. Nephrol Dial Transplant. 2017;32(2):234-41.

14. Wijkstrom J, Jayasumana C, Dassanayake R, et al. Morphological and clinical findings in Sri Lankan patients with chronic kidney disease of unknown cause (CKDu): similarities and differences with Mesoamerican nephropathy. PLoS ONE. 2018;13(3):e0193056.

15. Johnson RJ, Wesseling C, Newman LS. Chronic kidney disease of unknown cause in agricultural communities. N Engl J Med. 2019;380(19):1843-52.

16. Mani MK. Chronic renal failure in India. Nephrol Dial Transplant. 1993:8(8):684-9 (discussion 3). 
17. Farag YMK, Karai Subramanian K, Singh VA, et al. Occupational risk factors for chronic kidney disease in Andhra Pradesh: "Uddanam Nephropathy." Ren Fail. 2020;42(1):1032-41.

18. Aguilar-Ramirez D, Rana-Custodio A, Villa A, et al. Decreased kidney function and agricultural work: a cross-sectional study in middle-aged adults from Tierra Blanca, Mexico. Nephrol Dial Transpl. 2020. https://doi.org/10. 1093/ndt/gfaa041.

19. El Minshawy O. End-stage renal disease in the El-Minia Governorate, upper Egypt: an epidemiological study. Saudi J Kidney Dis Transpl. 2011;22(5):1048-54.

20. Delanaye P, Glassock RJ, Pottel $\mathrm{H}$, et al. An age-calibrated definition of chronic kidney disease: rationale and benefits. Clin Biochem Rev. 2016;37(1):17-26.

21. O'Hare AM, Choi Al, Bertenthal D, et al. Age affects outcomes in chronic kidney disease. J Am Soc Nephrol. 2007;18(10):2758-65.

22. Rigothier C, Chauveau B, Rubin S, et al. Chronic kidney disease of unknown origin in agricultural communities: beyond tropical mist? Nephrol Dial Transpl. 2020. https://doi.org/10.1093/ndt/gfaa265.

23. Nagai K, Asahi K, Iseki K, et al. Estimating the prevalence of CKD in Japan. Clin Exp Nephrol. 2021. https://doi.org/10.1007/s10157-021-02049-0.

24. Lebov JF, Valladares E, Pena R, et al. A population-based study of prevalence and risk factors of chronic kidney disease in Leon. Nicaragua Can J Kidney Health Dis. 2015;2:6.

25. Dally M, Butler-Dawson J, Krisher $L$, et al. The impact of heat and impaired kidney function on productivity of Guatemalan sugarcane workers. PLoS ONE. 2018;13(10):e0205181.

26. Bandara JM, Wijewardena HV, Liyanege J, et al. Chronic renal failure in Sri Lanka caused by elevated dietary cadmium: Trojan horse of the green revolution. Toxicol Lett. 2010;198(1):33-9.

27. Chandrajith R, Dissanayake CB, Ariyarathna T, et al. Dose-dependent Na and $\mathrm{Ca}$ in fluoride-rich drinking water-another major cause of chronic renal failure in tropical arid regions. Sci Total Environ. 2011;409(4):671-5.

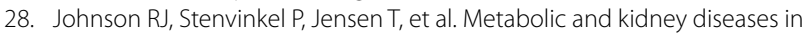
the setting of climate change, water shortage, and survival factors. J Am Soc Nephrol. 2016;27(8):2247-56.
29. Herath C, Jayasumana C, De Silva P, et al. Kidney diseases in agricultural communities: a case against heat-stress nephropathy. Kidney Int Rep. 2018;3(2):271-80

30. Weaver VM, Fadrowski JJ, Jaar BG. Global dimensions of chronic kidney disease of unknown etiology (CKDu): a modern era environmental and/or occupational nephropathy? BMC Nephrol. 2015;16:145.

31. Valcke M, Levasseur ME, Soares da Silva A, et al. Pesticide exposures and chronic kidney disease of unknown etiology: an epidemiologic review. Environ Health. 2017;16(1):49.

32. Nanayakkara S, Senevirathna ST, Abeysekera T, et al. An integrative study of the genetic, social and environmental determinants of chronic kidney disease characterized by tubulointerstitial damages in the North Central Region of Sri Lanka. J Occup Health. 2014;56(1):28-38.

33. Jayasumana C, Fonseka S, Fernando A, et al. Phosphate fertilizer is a main source of arsenic in areas affected with chronic kidney disease of unknown etiology in Sri Lanka. Springerplus. 2015;4:90.

34. Orantes $C M$, Herrera R, Almaguer $M$, et al. Chronic kidney disease and associated risk factors in the Bajo Lempa region of El Salvador: Nefrolempa study, 2009. MEDICC Rev. 2011;13(4):14-22.

35. Wesseling C, Aragon A, Gonzalez M, et al. Heat stress, hydration and uric acid: a cross-sectional study in workers of three occupations in a hotspot of Mesoamerican nephropathy in Nicaragua. BMJ Open. 2016;6(12):e011034

36. Athuraliya NT, Abeysekera TD, Amerasinghe PH, et al. Uncertain etiologies of proteinuric-chronic kidney disease in rural Sri Lanka. Kidney Int. 2011;80(11):1212-21.

37. Fitria L, Prihartono NA, Ramdhan DH, et al. Environmental and occupational risk factors associated with chronic kidney disease of unknown etiology in West Javanese rice farmers, Indonesia. Int J Environ Res Public Health. 2020;17(12):4521.

\section{Publisher's Note}

Springer Nature remains neutral with regard to jurisdictional claims in published maps and institutional affiliations.
Ready to submit your research? Choose BMC and benefit from:

- fast, convenient online submission

- thorough peer review by experienced researchers in your field

- rapid publication on acceptance

- support for research data, including large and complex data types

- gold Open Access which fosters wider collaboration and increased citations

- maximum visibility for your research: over 100M website views per year

At BMC, research is always in progress.

Learn more biomedcentral.com/submissions 